Iosr Journal Of Pharmacy

E-Issn: 2250-3013, P-Issn: 2319-4219

Www.Iosrphr.Org Volume 3, Issue 2 (March 2013), Pp 11-15

\title{
Ethnobotanical and Ethnopharmacognostical Survey on Medicinal Plants of Malon Village And Surrounding In The Cascades Region (Burkina Faso)
}

\author{
T.S. Sourabie ${ }^{1}$, N. Some ${ }^{1}$, O. Bognonou ${ }^{2}$, Y. Ouattara ${ }^{2}$, J.B. Ouedraogo ${ }^{3}$ \\ I, Département Médecine Et Pharmacopée Traditionnelles/Pharmacie (MEPHATRA/PH), IRSS/CNRST, O3 BP \\ 7192 Ouagadougou 03, Burkina Faso \\ 2, Département De La Production Forestière, Laboratoire De Botanique (INERA/CNRST), Ouagadougou, \\ Burkina Faso. \\ ${ }^{3}$ Institut Des Sciences Sociales, Centre National De La Recherche Scientifique Et Technologique \\ (INSS/CNRST), Ouagadougou, Burkina Faso.
}

\begin{abstract}
The authors present the results of an ethnobotanical and ethnopharmacognostical survey carried out in Malon and surroundings; Malon is a village located about $12 \mathrm{~km}$ far from Banfora, regional capital of the Cascades area form Burkina Faso. A multi disciplinary team of researchers gathering botanists, pharmacognisists, pharmacologists and ethnosociologists has undertaken that mission of investigation.The aim of the study was mainly centered on the inventory on the medicinal plants (MP) currently used in the traditional medicine of this area; and secondary, to collect data from traditional medical practices usually circulating. In this way, more than a hundred useful plants including 54 medicinal plants species have been inventoried, distributed across 32 families and 46 genera. Rubiaceae was the most dominant family (9,25\%), followed by Caesalpiniaceae (7,40\%), Apocynaceae (5,55\%), Asteraceae (5,55\%) and Meliaceae (5,55\%). Other families were found less than $2 \%$ of frequency.The results showed also a great number of traditional medical faith healers explaining thus the importance of the traditional medical practice for resolving healthcare problems in this community. Concerning the anthropomorphic pressure on the vegetal biodiversity due to the exploitation of natural resources, the impact was weak and presented no great danger even it constituted a reality.
\end{abstract}

KEYS WORDS: ethnobotanical and ethnopharmacognostical, Malon village medicinal plants, medical tradipractitioners.

\section{Introduction}

Ethnobotanical and ethnopharmacognostical investigations constitute an important factor to appreciate the medicinal potential of the vegetal biodiversity in Burkina Faso. According to many authors $[1,2,3,4,5,6]$, the medicinal plants represent one of the major components of the folk medicine in many African countries. The reason is due to the destitution of the great majority of populations (since more than the half population is under the threshold of poverty) who cannot get access to the modern medicine sold in pharmacies [7, 8].This report is updated in Burkina Faso where more than $70 \%$ of people still rely on medicinal plants for the treatment of various diseases [9]. Comparatively with Sudanese traditional medicine [10], the one of Burkina Faso according to many observers is also characterized by combination of knowledge and practices of all the communities living through the country. This medicine (traditional) is integrated in our culture, our customs and our social practices and is transmitted orally since several centuries $[11,12,13]$. So, the purpose of the present work was to make an inventory on the medicinal plants (MP) currently used in the medical traditional domain, to collect data from the medical traditional practices circulating in this area. The pressure of the medical traditional practices on the environment of medicinal plants was also another expected objective of the researcher group.

\subsection{Ethnology and study area}

\section{Material And Methods}

Malon is a small village belonging administratively to the department of Bérégadougou. It is about twelve $(12 \mathrm{~km})$ kilometers far from Banfora, the regional capital of Cascades area (Burkina Faso). Mainly the Turka, a dominant ethnic group originated from that area, composes the population. Beside this native population, there are other inhabitants comprising mossis (moâga), dioulas, fulfuldés, etc.The population of Malon village was estimated less than 2500 persons (in the moment of investigation period). Concerning the activities, the inhabitants of the village are in their great majority agricultural producers. They cultivate millet, maize, groundnuts, sorghum during the rainy season. In addition of supplies cultures, culture of cotton has been introduced and it becomes more and more predominant. 
The study area was in the surrounding of the village, including a vast vegetative zone along a little stream. An important gallery forest follows the course of the stream with abundant vegetation. The climate is typically tropical to sub-tropical, the average annual rainfall, temperature and humidity being $1000 \mathrm{~mm}, 27^{\circ} \mathrm{C}$ and $80 \%$, respectively. The forest gallery and all the vegetation of the study area were evergreen in that period.

\subsection{Methodological approach}

The study was performed during the end of November 1997 for a first time; other complementary investigations have been carried out later in 2005 and 2006. In all cases, a preliminary briefing, gathering the team of medical tradipractitioners (led by their elder named SOURA Mandjon) and the one of researchers was organized in order to precise the details of the daily task. The work was based on the reconnaissance of medicinal plants on the ground in the morning; and during the afternoon after coming back to the field trips, the other aspects (objectives) of the mission were evocated through discussions with the practitioners. The discussions were performed around the questions concerning pathologies circulating in the area, the impact of traditional medical practices on the environment of medicinal plants, etc.). The different specialists constituting the researchers team preciously collected all the data furnished by the medical tradipractitioners.For a good achievement of the mission, five (05) days of field trip have been necessary to make the inventory of medicinal plants through the study area. Specimens of plants were collected and authenticated by the botanists of researcher team; voucher specimens were also constituted for depositing in the laboratory of Botany Unit of the Institute (Dept. MEPHATRA/PH; IRSS-CNRST).

\subsection{RESULTS AND DISCUSSION}

During the present course of investigations, more than a hundred interesting plants have been discovered. Among these plants, 54 medicinal plant species used by Malon village population have been documented. These medicinal plant species were distributed across 32 families, 46 genera and 48 species (Table 1). In term of number of medicinal plants species, two (02) families were the most dominant; it was the case with Rubiaceae ( 5 species, 5 genera) of medicinal plants, followed by Caesalpiniaceae ( 4 species, 3 genera). In addition to the 2 precedent families, three (03) other families were documented, counting each three (3) species and were represented by Apocynaceae ( 3 species, 3 genera), Meliaceae ( 3 species, 3 genera) and Asteraceae ( 3 species, 2 genera). Among the families of medicinal plant species inventoried, five (05) of them have been distinguished to possess 2 species and twenty (20) others (families) were represented by only one specie (Table 1). The percentage of repartition of principle dominant families collected during the field trip is expressed on table 2 .

Table 1: Medicinal plants species, plants parts used and ailments cured by population of Malon village and surrounding.

\begin{tabular}{|c|c|c|c|c|}
\hline No & Species & Family & Part used & Uses \\
\hline 01 & Acacia nilotica & Caesalpiniaceae & Fruit & Antibacterial \\
\hline 02 & Afzlia africana & Caesalpiniaceae & Leaf, bark & Febrifuge, constipation \\
\hline 03 & Ageratum conyzoides $L$. & Asteraceae & Leaf & Cut, wound \\
\hline 04 & Allium cepa $L$. & Liliaceae & Bulb & Eye pain \\
\hline 05 & Alstonia scholaris $(L) B r$ & Apocynaceae & Leaf, bark & $\begin{array}{l}\text { Headache, stomach and } \\
\text { menstrual disorders, }\end{array}$ \\
\hline 06 & Argemone mexicana $L$. & Papaveraceae & Leaf, shoot & Malaria, jaundice, \\
\hline 07 & Azadirachta indica & Meliaceae & Leaf & Pharyngitis \\
\hline 08 & Begonia roxburghii (Miq) DC & Begoniaceae & Leaf & Indigestion \\
\hline 09 & Borrassus aethiopum & Arecaceae & Flowers & Antifungal \\
\hline 10 & Borreria verticillata $(\mathrm{L})$ GFW Mey & Rubiaceae & Leaf & Antibacterial \\
\hline 11 & Bridelia ferruginea & Euphorbiaceae & Leaf, roots, & Anemia \\
\hline 12 & Calotropis procera $L$. & Asclepiadaceae & Roots & Sicklemia \\
\hline 13 & Carica papaya $L$. & Caricacceae & Leaf, fruit & Jaundice \\
\hline 14 & Carissa edulis (Forssk.) & Apocynaceae & Roots & Abdominal pain \\
\hline 15 & Citrus aurantifolia $L$. & Rutaceae & Fruit & Cough, vomiting \\
\hline 16 & Combretum micranthum & Combretaceae & Leaf & Diuretic \\
\hline 17 & Combretum glutinosum Perr & Combretaceae & Leaf & $\begin{array}{l}\text { Antibacterial, } \\
\text { hypotension }\end{array}$ \\
\hline 18 & Chenopodium ambrosioides $L$. & Chenopodiaceae & Leaf & Toothache \\
\hline 19 & Crossopteryx febrifuga & Rubiaceae & Leaf & Fever, malaria \\
\hline 20 & Crotolaria pallida Ait. & Fabaceae & Roots & Bodyache \\
\hline 21 & Cymbopogon citratus (DC) & Poaceae & Leaf & Digestive \\
\hline 22 & Dioscorea alata $L$. & Dioscoreaceae & Tuber & Indigestion \\
\hline 23 & Entada africana Guill. et Per. & Mimosaceae & Leaf, roots & Inflammation \\
\hline 24 & Euphorbia hirta L. & Euphorbiaceae & Hole plant & Diarrhea, dysentery \\
\hline 25 & Ficus platyphylla Del. & Moraceae & Leaf & Antibacterial \\
\hline
\end{tabular}


Ethnobotanical And Ethnopharmacognostical Survey On...

\begin{tabular}{|c|c|c|c|c|}
\hline 26 & Hibiscus sabdariffa $L$. & Malvaceae & Flowers & Antibacterial \\
\hline 27 & Hyptis suaveolens (L). Poit. & Lamiaceae & Leaf & Cough, cold \\
\hline 28 & Khaya senegalensis & Meliaceae & Bark & Anti-inflammatory \\
\hline 29 & Lippia chevalieri & Verbenaceae & Leaf & Fever, cholagogue \\
\hline 30 & Maytenus senegalensis (Lam) & Celasteraceae & Leaf, roots & Laxative, dysentery \\
\hline 31 & Mitragyna inermis & Rubiaceae & Leaf & Antidiabete \\
\hline 32 & Mitracarpus scaber Zucc & Rubiaceae & Leaf & Skin treatment \\
\hline 33 & Moringa oleifera & Moringaceae & Leaf & Antibacterial \\
\hline 34 & Ocimum gratissimum & Lamiceae & Leaf & Antibacterial, \\
\hline 35 & Parkia biglobosa & Mimosaceae & Stem bark & $\begin{array}{l}\text { Anti-inflammatory, } \\
\text { antibacterial }\end{array}$ \\
\hline 36 & Paullinia pinnata $L$. & Sapindaceae & Roots, leaves & Erectile dysfunction \\
\hline 37 & Phyllanthus amarus Schumach. & Euphorbiaceae & Roots, leaves & Antiviral $\mathrm{C}$ hepatitis \\
\hline 38 & Piliostgma reticulatum (DC) Hochst & Fabaceae & Fruit (clove) & Food for animals \\
\hline 39 & Psidium guajava & Myrtaceae & Leaf & Diarrhea, dysentery \\
\hline 40 & Polygonum perfoliatum $L$. & Polygonaceae & Leaf & Indigestion \\
\hline 41 & Sarcocephalus latifolius & Rubiaceae & Roots, leaf & Spasmolytic, antibacterial \\
\hline 42 & Securidaca longepedunculata & Polygalaceae & Roots & Snake bite \\
\hline 43 & Senna alata (L) Roxb. & Caesalpiniaceae & Leaf & Skin disease, laxative \\
\hline 44 & Senna tora $(L)$ Roxb. & Caesalpiniaceae & Leaf & Low blood pressure \\
\hline 45 & Solanum nigrum $L$. & Solanaceae & Leaf & Sedative, antispasmodic \\
\hline 46 & Strophanthus gratus & Apocynaceae & Seed & Cardiotonic \\
\hline 47 & Tamarindus indica & Fabaceae & Seeds & Laxative \\
\hline 48 & Terminalia macroptera Guill. et Perr & Combretaceae & Fruit, leaf, Roots & Cough, snake bite \\
\hline 49 & Trichilia emetica Vahl & Meliaceae & Roots & Antibacterial, dermatitis \\
\hline 50 & Vitellaria paradoxa $G$. & Sapotaceae & Fruit & Butter, anti-inflammatory \\
\hline 51 & Vernonia cirenea $(L)$ & Asteraceae & Leaf & Indigestion \\
\hline 52 & Vernonia colorata $L$. & Asteraceae & Leaf & Antipyretic \\
\hline 53 & Xanthoxylum xanthoxyloides & Rutaceae & Roots & Sickle disease \\
\hline 54 & Zingiber officinale Rosc & Zingiberaceae & Rhizome & Cough \\
\hline
\end{tabular}

The prevalence of dominant families of medicinal plants collected varied between the main species inventoried as shows on table 2 below.

Table 2: dominant families of medicinal plants discovered in terms of number of species occupied.

\begin{tabular}{lcccc}
\hline \multicolumn{1}{c}{ Family } & Plants collected & Genera & Species & Prevalence (\%) \\
\hline Rubiaceae & 05 & 05 & 05 & 09,25 \\
Caesalpiniaceae & 04 & 03 & 04 & 07,40 \\
Apocynaceae & 3 & 3 & 3 & 5,55 \\
Meliaceae & 3 & 3 & 3 & 5,55 \\
Asteraceae & 3 & 2 & 3 & 5,55 \\
Other gathered families & & 30 & 30 & 66,7 \\
(27) & 36 & $\mathbf{4 6}$ & $\mathbf{4 8}$ & $\mathbf{1 0 0}$ \\
TOTAL & $\mathbf{5 4}$ & &
\end{tabular}

\subsection{Medicinal plants parts used for treatment}

According to the old traditional medical faith healer SOURA Manguion, the majority of the population of the village (Malon) is cured by traditional pharmacopeia. The reason was that modern health care services within the village (Malon and surrounding) were insufficient. For the treatment of diseases and others disorders affecting the villagers, different parts of medicinal plant species are used, particularly utilization of aboveground plant parts (leafs, fruits, seeds, stems, bark and flowers) and the belowground plant parts. Utilization of aboveground plant parts was higher $(68,52 \%)$ than the belowground plant parts $(31,48 \%)$. The results of all the plant parts used coming from aboveground and belowground are resumed in table 3.

Table 3: Profile of medicinal plants collected in Malon according to the plant parts used.

\begin{tabular}{cccc}
\hline $\begin{array}{c}\text { Aboveground plant } \\
\text { parts used }\end{array}$ & $\begin{array}{c}\text { Number of } \\
\text { plants }\end{array}$ & $\begin{array}{c}\text { Belowground plant } \\
\text { parts used }\end{array}$ & Number of plants \\
\hline Leaf & 24 & Roots & 14 \\
Fruit & 6 & Rhizome & 1 \\
Seed & 2 & Bulb & 1 \\
Bark & 3 & - & - \\
Flower & 3 & - & - \\
TOTAL & $\mathbf{3 8}$ & TOTAL & $\mathbf{1 6}$ \\
\hline
\end{tabular}




\section{State Of Circulating Sickness}

Information collected from the traditional faith healers indicated that Malon and its surrounded area don't escape from the pathologies which circulate in that extreme south west region of Burkina Faso. Several types of illness circulate through the area of Malon village (malaria, gastroenteritis, intestinal parasites disease, infectious ailments like meningitis, bronchitis, etc.). Some of ailments have a seasonal profile in their manifestation; but in general two periods have been distinguished. In the rainy season featured by a great humidity due to abundant rainfalls (since the area is one of the best watered of Burkina Faso), many cases of malaria sickness have been signaled, affecting particularly the low aged children. Beside malaria disorder, hydric pathologies as diarrhea, dysentery and other illness like worm infections were found also to be increased. Specific pathologies relative to the dry season have been equally noted. Some rare cases of meningitis occurred but not epidemically. Respiratory infections, parasites and bacterial diseases (gastroenteritis, worm diseases, eyes sickness, etc have equally inventoried. They constitute according to the traditional faith healers of Malon the current sickness frequently met. For the treatment of all these pathologies, the traditional healers of Malon possess a great traditional medical knowledge, which helps them to take care of the patients. The medicinal plants recipes destined to the treatment of the patients are composed in certain cases by several elements: root barks or stem barks, leaves, whole plant, flowers, etc. The combination of several plant parts is frequently used by the faith healers in the cure of certain pathologies such as malaria fever where an aqueous decoction can be prepared by combination resulting from the association of the Neem leaves (Azadirachta indica, Meliaceae) with those (leaves) of Vernonia colorata (Asteraceae). The ailments cured by the healers in terms of using medicinal plants are resumed below (Table 4).

Table 4: Major sickness cured by Malon traditional healers using medicinal plants.

\begin{tabular}{lc}
\hline \multicolumn{1}{c}{ Ailments } & Number of plants used (treatment) \\
\hline Malaria & 12 \\
Diarrhea & 5 \\
Dysentery & 4 \\
Cough and cold & 7 \\
Infectious diseases & 6 \\
Respiratory infectious & 2 \\
Fever & 8 \\
Stomach disorder & 5 \\
Indigestion & 6 \\
\hline
\end{tabular}

\subsection{Impact of medicinal plants in Malon area}

The ethno-medico-botany investigation sustained by a pharmacognostical survey in Malon showed an increasing interest of medicinal plants for resolving the health problems in the village. The fifty medicinal plant species (exactly 54) inventoried were used in curing several types of diseases of which an important number of plants species were utilized to cure malaria (Table 4). Among the medicinal plants exploited by the population for curing ailments, some of them presented dietary and economical interest. It was the case of Parkia biglobosa (Mimosaceae), Vittelaria paradoxa (Sapotaceae) and Borassus aethiopum (Arecaceae).These three species vegetal (plants), in addition to their medicinal properties, are edible by their fruits and they are among the most popular plants of the Cascades Region. Nowadays the region of Cascades is symbolized in the all-regional official administrative documents by Borassus aethiopum (Arecaceae). The tree presents another interest that resides in the extraction of the plant sap called bandji in local dialect. It is a comfort sweet drink sold in the market places. The reputation of Cascades region is particularly due to that drink which can be fermented, thus meaning an alcoholic drink whose consumption can exhibit to grave consequences. The trunk of B. aethiopum is used carpentry in the construction of houses and the leaves serve to make up the mats. In addition, the fruit of $P$. biglobosa gives an edible sweet yellow pulp, which is very appreciated by children. Women equally sell that pulp transformed in powder during the market days. About the seeds, they can be transformed also to obtain product called in local name "Soumbala" and is used in the kitchen to season the sauce. The findings of Hassanata Koné [14] have revealed anti-hypertension property with soumbala.The data obtained from Vitellaria paradoxa, revealed a great interest of this plant due to the fruits which produce not only an edible sweet pulp, but also the seeds serve to extract oil called "beurre de karité". Butter produced by the seeds of Vitellaria paradoxa is destined to the feeding; it is equally used in pharmaceutical industry as excipient to make up suppositories.All these results obtained from the traditional healers during that survey showed the perfect symbiosis between the inhabitants of Malon area and their environment. Moreover, the richness and the density of vegetal biodiversity are such as, the needs of population in healthcare products don't constitute for the moment a big preoccupation. The good climatic conditions (abundant rains, constant humidity and temperatures quietly soft) that characterize this part of the country (Burkina Faso) permit to entertain the development of luxurious vegetation, which provides the people of Malon village and surrounding all the medical products needed to resolve their sanitary problems. 


\section{The Future Of Medicinal Plant Resources In Malon}

Before the present investigations, no previous studies have been carried out in Malon area. The inventory of 54 medicinal plant species gives hope to the researchers in medicinal plants domain. Indeed, as advocated by authors as Chandra Prakash et al. [13], Dutta et al., [15] and El-Kamali [12], a need for detailed surveys of ethnobotanical and pharmacognostical knowledge held by the different tribal communities of Malon is required before such valuable knowledge vanishes. That area of Malon and beyond in the region of Cascades offers to the researchers real possibilities to make inventory of countless medicinal plants species.Ethnomedicinal knowledge is very important from a humanitarian point of view and this (knowledge) may help to identify interesting medicinal plant uses that can help in curing and healthcare around the world [13]. The results of the present survey led in the Cascades area, particularly in Malon village and surroundings, open new avenues to scrutinize such a rich natural resource for further analysis in order to develop the potential of herbal medicine.

\section{Conclusion}

This study understood in Malon village and surroundings have permitted to appreciate the richness and the diversity of medicinal plant species inventoried. Some of them have been studied phytochemically and pharmacologically in the Department MEPHATRA/PH laboratories of the Institute (IRSS/CNRST) but many of the collected plants still remained non investigated scientifically; all thing which constitutes a new challenge for the researchers of MEPHATRA/PH department.

\section{Acknowledgements.}

The authors are grateful to the old medical traditional practitioner SOURA Mandjon and his team for their collaboration during all the different steps of this work, particularly the field trips investigation. The authors also express their gratefulness to the other traditional faith healers of Bérégadougou and Fabédougou (Cacades region, Comoé Province) whose contribution has been welcome for the achievement of results obtained during this ethnobotanical and pharmacognostical investigations.

\section{References}

[1]. Adjanohoun E.J., Aké Assi L., Loret J.J., Guinko S., Koumaré M., Ahyi Amr, Raynal J. (1979). Contribution Aux Etudes Ethnobotaniques Et Floristiques Au Mali. Paris : ACCT : 291

[2]. Adjanohoun E.J. (1989). La Voie Des Enquêtes Ethnobotaniques Pour Les Pharmacopées Africaines. Bull. Méd. Trad. Pharm., Vol. 3, $\mathrm{N}^{\circ} 1$, Pp. 47-51

[3]. Adjanohoun E.J. Et Al. (1986). Contribution Aux Etudes Ethnobotaniques Et Floristiques Au Togo. Paris : ACCT : 671.

[4]. Adjanohoun E.J. (1994). Contribution Aux Etudes Ethnobotaniques Et Floristiques Au Bénin. ACCT, 1986. In Rev Méd Pharm Afrric. Vol 8(2). Paris, ACCT: 237.

[5]. Bélem Et Al. (2006). Potentialités Des Galleries Forestières De La Réserve De Biosphère De La Mare Aux Hippopotames A L'ouest Du Burkina Faso: Cas Des Plantes Médicinales. 11ème Colloque International Sur Le Développement, Environnement Et Santé, Bamako, 12-16 Juin.

[6]. Céa Benjamin (2006). Plantes Médicinales Et Pharmacopée : Impact De L'exploitation Des Plantes Médicinales Sur La Réserve De Biosphère De La Mare Aux Hippopotames (RBMH). Rapport De Mission D'enquête, Avril-Juin 2006, 48p.

[7]. T.S. Sourabié, H.M. Koné J.B. Nikiéma, O.G. Nacoulma and I.P.Guissou (2009). antihepatoxic effect of Argemone mexicana leaf extract against $\mathrm{CCl}_{4^{-}}$ Biol. Chem. Sci. 3(6): 1499-1503, December 2009.

[8]. Léga Ibrahim (2010). Evaluation des propriétés antibactériennes in vitro d'extraits de feuilles d'Argemone mexicana L. (Papaveraceae). Thèse de Doctorat en Pharmacie, UFR/SDS, Université de Ouagadougou, pp.62.

[9]. Institut National de la Statistique et de la Démographie (INSD), 2007. Analyse des résultats de l'enquête sur les conditions de vie des ménages en 2007. Ouagadougou: INSD, Octobre 2007.

[10]. Sourabié T.S. (2006). Enquêtes ethnobotaniques et ethnopharmacognosiques dans la zone de la mare aux hippopotames de Bala. Rapport de mission du Projet MAB du 16 au 23 mars ; 11p.

[11]. Sourabié T.S. (2008). Capitalisation et synthèse des résultats de recherche sur les plantes médicinales et alimentaires de la réserve de biosphère de la Mare aux Hippopotames (RBMH). Rapport de synthèse, Projet MAB ; Mars $2008 ; 49$ p.

[12]. H.H. El-Kamali, S.A. Khalid, (1998). The most common herbal remedies in Dongola Province. Northen Sudan. Fitoterapia, Vol. LXIX, N²: pp. 118-120.

[13]. Chandra Prakash Kala (2005). Ethnomedicinal botany of the Apatani in the Eastern Himalayan region of India. Journal of Ethnobiology and Ethnomedicine, I:11; pp. 1-8.

[14]. Millogo/Koné (2008)- Etude de la phytochimie et des activités biologiques d'extraits de Parkia biglobosa (Jacq.) Bent (Mimosaceae). Thèse de Doctorat d'Etat, UFR/SVT, Université de Ouagadougou, 169 pages.

[15]. M.L. Dutta, S.G. Nath (1998). Ethno-medico botany of Deories of Assam, India. Fitoterapia, Vol. LXIX, N², pp. 147-154. 